\title{
Synthesis, Characterization, and Thermal Study of Divalent Germanium, Tin, and Lead Triazenides as Potential Vapor Deposition Precursors
}

\author{
Rouzbeh Samii, David Zanders, Anton Fransson, Goran Bačíc, Sean T. Barry, Lars Ojamäe, \\ Vadim Kessler, Henrik Pedersen, and Nathan J. O’Brien*
}

Cite This: Inorg. Chem. 2021, 60, 12759-12765

Read Online

ACCESS | Lلll Metrics \& More | 回 Article Recommendations | st Supporting Information

ABSTRACT: Only a few $\mathrm{M}-\mathrm{N}$ bonded divalent group 14 precursors are available for vapor deposition, in particular for $\mathrm{Ge}$ and $\mathrm{Pb}$. A majority of the reported precursors are dicoordinated with the $\mathrm{Sn}$ (II) amidinates, the only tetracoordinated examples. No $\mathrm{Ge}(\mathrm{II})$ and $\mathrm{Pb}(\mathrm{II})$ amidinates suitable for vapor deposition have been demonstrated. Herein, we present tetracoordinated $\mathrm{Ge}(\mathrm{II}), \mathrm{Sn}(\mathrm{II})$, and $\mathrm{Pb}(\mathrm{II})$ complexes bearing two sets of chelating 1,3-di-tert-butyltriazenide ligands. These compounds are thermally stable, sublime quantitatively between 60 and $75{ }^{\circ} \mathrm{C}$ (at $0.5 \mathrm{mbar}$ ), and show ideal single-step volatilization by thermogravimetric analysis.

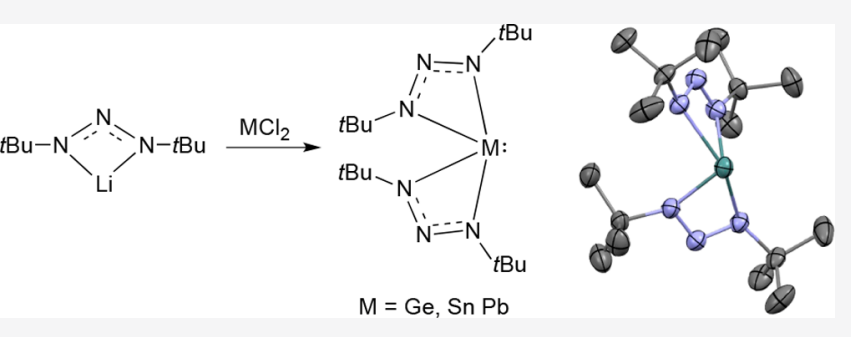

\section{INTRODUCTION}

Group 14 chalcogenides are of interest because of their outstanding electrical and optical properties. ${ }^{1}$ In particular, monochalcogenides such as germanium sulfide $(\mathrm{GeS}){ }^{2}$ germanium selenide $(\mathrm{GeSe}),{ }^{2}$ tin sulfide $(\mathrm{SnS}),{ }^{2-9}$ tin selenide $(\mathrm{SnSe})^{2,10-12}$ and lead sulfide $(\mathrm{PbS})^{13-19}$ have potential applications in future optoelectronics and photovoltaics. Manufacturing these electronic devices requires highly controlled deposition of conformal, dense, and defect-free films with low impurity levels. High-quality thin films are commonly grown by chemical vapor deposition (CVD) methods. One subset of CVD is atomic layer deposition (ALD), which is a low-temperature alternative that introduces the metal and nonmetal precursors into the reaction chamber separately in alternating pulses. ${ }^{20}$ This separation allows the deposition process to be governed exclusively by self-limiting chemical reactions on the growth surface. To obtain highquality films by ALD, it is important to have metal and nonmetal precursors that possess favorable physical and chemical properties. ${ }^{21}$ An ALD precursor must be sufficiently volatile for gas-phase transport to the growth region. It should not decompose in the gas phase in a manner that leads to continuous CVD growth. ${ }^{22}$ At the surface, the precursor should react in a self-limiting manner to form a stable monolayer and easy-to-purge byproducts. ${ }^{23}$ After purging, the monolayer should react with a second precursor (e.g. $\mathrm{H}_{2} \mathrm{~S}$ and $\mathrm{H}_{2} \mathrm{O}$ ) in a second self-limiting reaction. To maximize film growth, the precursor should employ small ligands for effective surface saturation and dense coverage. ${ }^{24}$ Furthermore, using precursors of the same oxidation state as the target material removes the need for redox chemistry during deposition. Not having to rely on redox chemistry for the deposition process reduces the risk of forming undesired mixed-phase materials. Precursors with $\mathrm{M}-\mathrm{N}$ bonds are desirable for ALD because of the high reactivity of the polarized bond. To date, there is only a small library of exclusively $\mathrm{M}-\mathrm{N}$ bonded $\mathrm{Ge}(\mathrm{II}), \mathrm{Sn}(\mathrm{II})$, and $\mathrm{Pb}$ (II) precursors suitable for ALD. Figure 1 shows the general structures of some precursors used for growing group 14 monochalcogenides that are discussed.
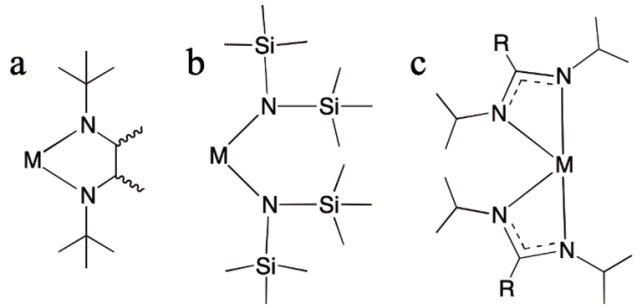

Figure 1. General structures of divalent group 14 (a) cyclic diamide, (b) hexamethyldisilazide, and (c) amidinates, where $\mathrm{M}=\mathrm{Ge}, \mathrm{Sn}$, and $\mathrm{Pb}$. For formamidinate and amidinates, $\mathrm{R}=\mathrm{H}$ and $\mathrm{CH}_{3}$, respectively. These are the $\mathrm{M}-\mathrm{N}$ bonded compound classes that have been utilized as ALD precursors for depositing group 14 chalcogenides.

Received: March 7, 2021

Published: August 6, 2021 
Scheme 1. General Procedure for Making $1-3^{a}$

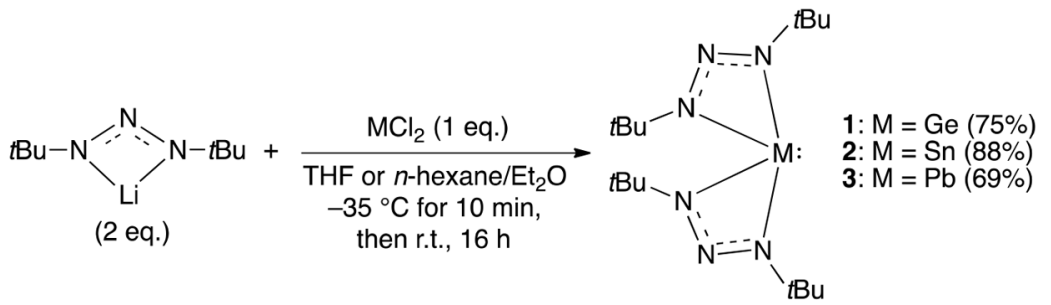

${ }^{a_{T}}$ The synthesis of $\mathbf{1}$ was carried out in tetrahydrofuran (THF), while the syntheses of $\mathbf{2}$ and $\mathbf{3}$ were carried out in a 1:4 mixture of diethyl ether $\left(\mathrm{Et}_{2} \mathrm{O}\right)$ and $n$-hexane.
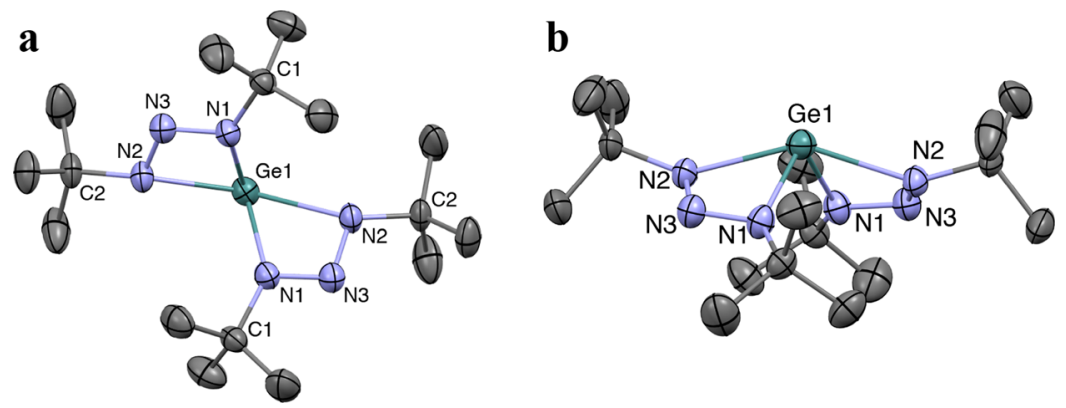

Figure 2. Crystal structure of $\mathbf{1}$ viewed (a) parallel and (b) perpendicular to the stereochemically active lone pair residing on the Ge atom. Thermal ellipsoids are depicted at the $50 \%$ probability level, and all $\mathrm{H}$ atoms were removed for clarity.

The dicoordinated Ge(II) cyclic diamide and hexamethyldisilazide compounds have been used to deposit $\mathrm{GeS}^{25}$ and $\mathrm{GeSe}^{26}$ by ALD, respectively. However, the deposited $\mathrm{GeS}$ was $\mathrm{X}$-ray amorphous, while the GeSe films contained unwanted carbon impurities. SnS has been demonstrated by ALD using the dicoordinated cyclic diamide and, tetracoordinated $\mathrm{Sn}$ (II) formamidinate and amidinate precursors. ${ }^{27,28}$ The amidinate ligand system provides tetracoordinated, thermally stable, and volatile precursors that afford stochiometric $\operatorname{SnS}$ with low levels of impurities.

Recently, $\mathrm{PbS}$ was deposited using the dicoordinated $\mathrm{Pb}-\mathrm{N}$ bonded hexamethyldisilazide and cyclic diamide precursors, rendering near stochiometric films with low levels of carbon impurities. ${ }^{29}$ However, the deposition temperature for ALD growth was limited to $\leq 155{ }^{\circ} \mathrm{C}$ due to the poor thermal stability of the deposited surface species. Volatility data have not been reported for the tetracoordinated $\mathrm{Ge}$ (II) and $\mathrm{Pb}$ (II) amidinates in the literature. ${ }^{30,31}$ There are no other exclusively $\mathrm{M}-\mathrm{N}$ bonded tetracoordinated $\mathrm{Ge}$ (II) and $\mathrm{Pb}$ (II) compounds used as precursors for ALD, as far as we know.

A ligand system closely related to the amidinates is the triazenide, where the endocyclic $\mathrm{C}$ is replaced by $\mathrm{N}$. There are reports of tetracoordinated divalent group 14 triazenides. ${ }^{32}$ There is no mention of their volatility, and these compounds are most likely not suitable for vapor deposition because of their bulky 1,3-bis(2,6-diisopropylphenyl)triazenide ligand. Recently, we explored the 1,3-dialkyltriazenide ligand for group 13 metals and used the $\mathrm{In}$ (III) and $\mathrm{Ga}$ (III) 1,3diisopropyltriazenide precursors for ALD of InN and GaN. ${ }^{33-35}$ To further explore the 1,3-dialkyltriazenide ligand, we envisaged its ability to stabilize divalent group 14 elements. This would potentially give a new class of tetracoordinated $\mathrm{M}-\mathrm{N}$ bonded group 14 precursors for ALD. Herein, we present the synthesis, characterization, and thermal study of $\mathrm{Ge}(\mathrm{II}), \mathrm{Sn}(\mathrm{II})$, and $\mathrm{Pb}(\mathrm{II})$ compounds bearing two sets of the 1,3-di-tert-butyltriazenide ligand. Their high volatility and thermal stability make these group 14 triazenides interesting for use as ALD precursors.

\section{RESULTS AND DISCUSSION}

Synthesis and Characterization of Triazenides 1-3. The reaction of (1,3-di-tert-butyltriazenide) lithium with $\mathrm{MCl}_{2}$, where $\mathrm{M}=\mathrm{Ge}, \mathrm{Sn}$, or $\mathrm{Pb}$, gave $\mathbf{1 - 3}$ in good yields after recrystallization (Scheme 1; CCDC 2058914, 2058915, and 2058916 for $\mathbf{1 - 3}$, respectively). Compounds $\mathbf{1} \mathbf{- 3}$ are air- and moisture-sensitive and low-melting yellow solids. The compounds were characterized by NMR spectroscopy, X-ray crystallography, electron impact mass spectrometry, elemental analysis, and melting point measurement.

The ${ }^{1} \mathrm{H}$ NMR spectra of compounds $1-3$ showed a singlet between 1.30 and $1.40 \mathrm{ppm}$, indicating fast exchange for all protons of the tert-butyl groups. The ${ }^{13} \mathrm{C}$ NMR spectra of 1-3 gave the primary and quaternary $C$ peaks at 30.5-30.6 and 58.9-61.1 ppm, respectively. All NMR spectra are presented in the Supporting Information.

The crystal structure of 1 showed two chelating 1,3-di-tertbutyltriazenide ligands on the metal center (Figure 2). Both ligands are forced to the same side of the metal center by a stereochemically active lone pair, situated on the opposite side (Figure $2 \mathrm{~b}$ ). The coordination of the Ge atom is best described as a distorted seesaw geometry, as suggested by a geometry index $\left(\tau_{4}^{\prime}\right)$ of $0.65 .^{36}$ See the Supporting Information for the geometry index calculations for compounds $1-3$ and the crystal structures of compounds 2 and 3 . Compounds 2 and 3 have crystal structures and molecular geometries analogous to that of $\mathbf{1}$. However, the $\mathrm{Sn}$ and $\mathrm{Pb}$ centers are further distorted toward tetrahedral geometry $\left(\tau^{\prime}{ }_{4}=0.82\right.$ and 0.86 for 2 and 3, respectively). The $\beta$ angle decreases in the order $1>2>3$. This trend can be explained by a greater $\mathrm{p}$ character of the $\mathrm{M}-$ $\mathrm{N}$ bond when moving down the group (Table 2).

The geometries of $\mathbf{1 - 3}$ are in good agreement with previously reported analogs $\mathbf{1 A}-\mathbf{3 A},{ }^{32}$ which employ the 
bulkier 2,6-diisopropylphenyl $\mathrm{R}$ groups in place of tert-butyl (Tables 1 and 2).

Table 1. Average Bond Lengths $(\AA)$ for $1-3(\mathrm{R}=$ tert-butyl) and Their Respective Analogs $1 A-3 A(R=2,6-$ diisopropylphenyl)

\begin{tabular}{|c|c|c|c|c|c|c|c|}
\hline \multirow{5}{*}{ 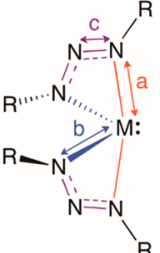 } & & \multicolumn{2}{|c|}{$\mathrm{Ge}$} & \multicolumn{2}{|c|}{$\mathrm{Sn}$} & \multicolumn{2}{|c|}{$\mathrm{Pb}$} \\
\hline & & 1 & $1 \mathrm{~A}$ & 2 & $2 \mathrm{~A}$ & 3 & $\mathbf{3 A}$ \\
\hline & $\mathrm{a}$ & 2.217 & 2.195 & 2.388 & 2.339 & 2.503 & 2.46 \\
\hline & b & 1.995 & 2.008 & 2.207 & 2.223 & 2.326 & 2.35 \\
\hline & c & 1.31 & 1.31 & 1.31 & 1.31 & 1.29 & 1.30 \\
\hline
\end{tabular}

Table 2. Average Bond Angles (deg) for $1-3(\mathrm{R}=$ tertbutyl) and Their Respective Analogs 1A-3A ( $R=2,6$ diisopropylphenyl)

\begin{tabular}{|c|c|c|c|c|c|c|c|}
\hline \multirow{6}{*}{$\mathrm{R}^{\prime \cdots . . . N}$} & & \multicolumn{2}{|c|}{$\mathrm{Ge}$} & \multicolumn{2}{|c|}{ Sn } & \multicolumn{2}{|c|}{$\mathrm{Pb}$} \\
\hline & & 1 & $1 \mathrm{~A}$ & 2 & $2 \mathrm{~A}$ & 3 & 3A \\
\hline & $\alpha$ & 98.2 & 104.7 & 93.99 & 101.4 & 92.13 & 100.5 \\
\hline & $\beta$ & 147.9 & 137.37 & 133.39 & 129.18 & 129.61 & 125.5 \\
\hline & $\gamma$ & 59.64 & 59.61 & 54.87 & 55.3 & 52.54 & 52.8 \\
\hline & $\eta$ & 107.35 & 106.7 & 110.27 & 108.4 & 112.21 & 109.5 \\
\hline
\end{tabular}

The geometries of 1-3 obtained from quantum-chemical density functional theory (DFT) computations are in good agreement with their crystal structures (see the Supporting Information). The stereochemically active lone pair resides in the highest occupied molecular orbital (HOMO; displayed for 1 in Figure 3).

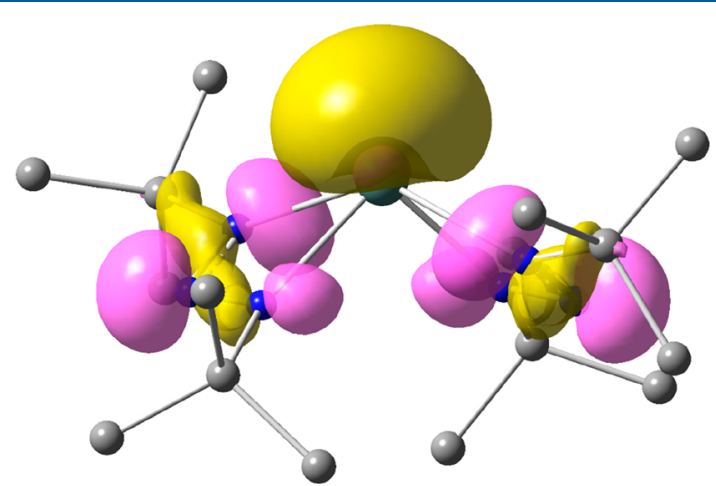

Figure 3. HOMO for $\mathbf{1}$ obtained from DFT calculations. $\mathrm{H}$ atoms are omitted for clarity. The stereochemically active lone pair occupies a large part of the coordination sphere of the metal center.

Thermal Properties of Triazenides 1-3. Thermogravimetric analysis (TGA) showed $\mathbf{1 - 3}$ volatilize in a single-step with onset temperatures between 137 and $152{ }^{\circ} \mathrm{C}$, and negligible residual mass (Figure 4 and Table 3). Compounds 1 and $\mathbf{3}$ are therefore the first examples of volatile tetracoordinated $\mathrm{M}-\mathrm{N}$ bonded $\mathrm{Ge}(\mathrm{II})$ and $\mathrm{Pb}(\mathrm{II})$ compounds, making them potentially useful as vapor deposition precursors. When comparing TGA data, compound $\mathbf{2}$ appears only slightly less volatile than $\mathrm{Sn}$ (II) formamidinate. ${ }^{28}$ This result is noteworthy as $\mathrm{Sn}$ (II) formamidinate is the most volatile tetracoordinated $\mathrm{M}-\mathrm{N}$ bonded compound to date. The TGA data show 1-3

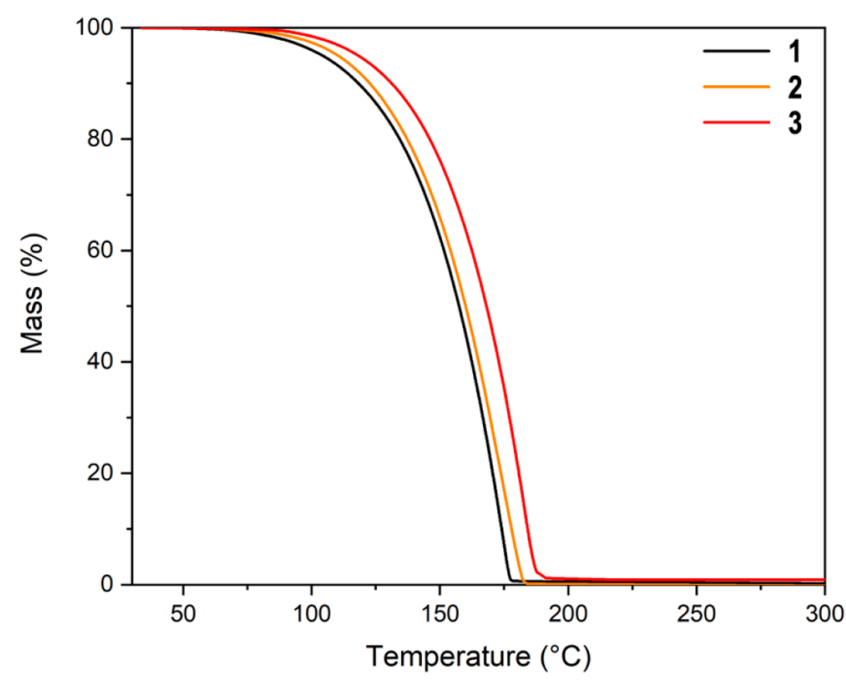

Figure 4. TGA of compounds 1-3 (10 mg samples) showing nearideal single-step volatilization with negligible residual mass.

Table 3. Summarized TGA and DSC Results for 1-3

\begin{tabular}{cccccc} 
DSC & $\begin{array}{c}\text { onset of } \\
\text { decomp } \\
\text { exotherm } \\
\text { onset }\left({ }^{\circ} \mathrm{C}\right)\end{array}$ & $\begin{array}{c}\text { residual } \\
\text { volatilization } \\
\left({ }^{\circ} \mathrm{C}\right)\end{array}$ & $\begin{array}{c}\text { mass } \\
(\%)\end{array}$ & $\begin{array}{c}\text { temp at } 1 \\
\text { Torr of vapor } \\
\text { pressure }\left({ }^{\circ} \mathrm{C}\right)\end{array}$ & $\begin{array}{c}\text { sublimation } \\
\text { temp }\left({ }^{\circ} \mathrm{C}\right)^{1}\end{array}$ \\
\hline $\mathbf{1}$ & 181 & 137 & 0 & 87 & 60 \\
$\mathbf{2}$ & 280 & 140 & 0 & 96 & 65 \\
$\mathbf{3}$ & 170 & 152 & 0 & 103 & 75
\end{tabular}

${ }^{1}$ Sublimations were performed at $0.5 \mathrm{mbar}$ of pressure.

are highly volatile, exhibiting 1 Torr of vapor pressures between $\sim 90$ and $100{ }^{\circ} \mathrm{C}$ (Table 3). Compounds $\mathbf{1}-\mathbf{3}$ sublime quantitatively between 60 and $75{ }^{\circ} \mathrm{C}$ under reduced pressure (0.5 mbar).

Differential scanning calorimetry (DSC) of $\mathbf{1}$ showed overlapping exotherms at $181{ }^{\circ} \mathrm{C}$ indicated by the irregular peak shape. The compound degraded when heated to $200{ }^{\circ} \mathrm{C}$ in a sealed capillary, suggesting the exotherm is a decomposition event. Compound 2 gave an exotherm at 175 ${ }^{\circ} \mathrm{C}$, preceded by a small peak at $160{ }^{\circ} \mathrm{C}$. However, it remained intact when heated to $200{ }^{\circ} \mathrm{C}$ for $24 \mathrm{~h}$, indicating the exotherms at $160^{\circ} \mathrm{C}$ and $175{ }^{\circ} \mathrm{C}$ are not decompositon events. A third exotherm was found at $280{ }^{\circ} \mathrm{C}$ and is most likely a decomposition event as the compound released gas bubbles during melting and changed from a yellow liquid to an offwhite solid when heated to $275{ }^{\circ} \mathrm{C}$ in a sealed capillary. Compound 3 showed an exotherm at $85{ }^{\circ} \mathrm{C}$, but the melt resolidified, and the melting point was unaffected by repeated heating of the compound to $110{ }^{\circ} \mathrm{C}$ for hours in sealed capillaries. The heat-treated compound remained unchanged from pure 3 , both visually and by ${ }^{1} \mathrm{H}$ NMR analysis, suggesting the exotherm at $85^{\circ} \mathrm{C}$ is not a decomposition event. A second exotherm of sharp overlapping signals was found at $170{ }^{\circ} \mathrm{C}$. This exotherm at $170{ }^{\circ} \mathrm{C}$ is most likely a decomposition event as the compound darkened when heated above $180{ }^{\circ} \mathrm{C}$ in a sealed capillary. Upon cooling, the melt resolidified into an inhomogeneous, yellow and gray solid. A third exotherm was observed between 270 and $300{ }^{\circ} \mathrm{C}$. The sublimation temperatures of 1-3 and their TGA and DSC data are summarized in Table 3. See the Supporting Information for individual TGA and DSC data. 
Disregarding the first exotherm for 3, compounds $1-3$ have onsets of decomposition from DSC well above their respective onsets of volatilization from TGA. DSC revealed no thermal events occurring for $\mathbf{1}$ and $\mathbf{2}$ at temperatures $<100{ }^{\circ} \mathrm{C}$, consistent with the observations during melting point measurements.

\section{CONCLUSIONS}

In summary, we have presented volatile divalent $\mathrm{Ge}, \mathrm{Sn}$, and $\mathrm{Pb}$ triazenides as potential precursors for vapor deposition. To our knowledge, $\mathbf{1}$ and $\mathbf{3}$ are the first examples of tetracoordinated and exclusively $\mathrm{M}-\mathrm{N}$ bonded $\mathrm{Ge}(\mathrm{II})$ and $\mathrm{Pb}(\mathrm{II})$ compounds with high volatility and thermal stability. The compounds sublime quantitatively between 60 and $75{ }^{\circ} \mathrm{C}$ (at 0.5 mbar), and show near-ideal volatilization by TGA with onsets between $\sim 130$ and $160{ }^{\circ} \mathrm{C}$.

\section{EXPERIMENTAL SECTION}

General Experimental Procedures. Caution! Because catenated nitrogen compounds are known to be associated with explosive hazards, tert-butylazide and compounds 1-3 are possible explosive energetic materials. Although we have not experienced any problems in the synthesis, characterization, sublimation, heating, and handling of compounds 1-3, their energetic properties have not been fully investigated and are therefore unknown. We therefore highly recommend all appropriate standard safety precautions for handling explosive materials (safety glasses, face shield, blast shield, leather gloves, polymer apron, and ear protection) always be used when working with tert-butylazide and compounds 1-3. In addition, keep tert-butylazide and compounds 1-3 away from other metals ( $\mathrm{Cu}$ and $\mathrm{Ag}$ ) and $\mathrm{Hg}$ bubblers while using Schlenk equipment.

All reactions and manipulations were carried out under a $\mathrm{N}_{2}$ atmosphere, either on a Schlenk line using Schlenk air-free techniques or in a dry box. All anhydrous solvents were purchased from SigmaAldrich and further dried over molecular sieves $4 \AA$. The $\mathrm{GeCl}_{2}$. dioxane complex, $\mathrm{SnCl}_{2}$ (98\%) and $\mathrm{PbCl}_{2}$ (98\%), and a tertbutyllithium solution (1.7 $\mathrm{M}$ in pentane) were purchased from Sigma-Aldrich and used without further purification. The preparation of tert-butylazide was undertaken according to the literature procedure. $^{37}$ All NMR spectra were measured with Oxford Varian 300 and AS500 spectrometers at room temperature unless otherwise stated. Solvent peaks were used as internal standards for ${ }^{1} \mathrm{H}$ NMR $(300$ and $500 \mathrm{MHz})$ and ${ }^{13} \mathrm{C}$ NMR $(75$ and $125 \mathrm{MHz})$. Electron ionization mass spectrometry (EI-MS) was performed with a Kratos Concept-Magnetic sector mass spectrometer in high-resolution mode. Melting points were determined in sealed capillaries with a Stuart SMP10 melting point apparatus and are uncorrected. Elemental analyses were performed by Mikroanalytisches Laboratorium Kolbe, Germany.

Synthesis of the Triazenide Ligand and Compounds 1-3. Lithium 1,3-Di-tert-butyltriazenide Ligand. tert-Butyllithium (1.7 M in pentane, $110 \mathrm{~mL}, 187 \mathrm{mmol}$ ) was added dropwise to a solution of tert-butylazide $(18.6 \mathrm{~g}, 188 \mathrm{mmol})$ in $n$-hexane $(150 \mathrm{~mL})$ at $-78^{\circ} \mathrm{C}$. The reaction mixture was stirred for $30 \mathrm{~min}$ and then allowed to warm to room temperature for $1 \mathrm{~h}$. The reaction mixture was then concentrated under reduced pressure to give a light-yellow solid (29.7 g, 97\%). This solid was of sufficient purity to be used in the subsequent reactions without further purification. A small amount was purified for characterization by recrystallization from $n$-hexane at -35 ${ }^{\circ} \mathrm{C}$ to give a solid. Colorless solid, mp: $247-250{ }^{\circ} \mathrm{C} .{ }^{1} \mathrm{H}$ NMR (300 $\left.\mathrm{MHz}, \mathrm{C}_{6} \mathrm{D}_{6}\right): \delta 1.28\left(\mathrm{~s}, \mathrm{CH}_{3}, 18 \mathrm{H}\right) .{ }^{13} \mathrm{C}\left\{{ }^{1} \mathrm{H}\right\} \operatorname{NMR}\left(75 \mathrm{MHz}, \mathrm{C}_{6} \mathrm{D}_{6}\right)$ : $\delta 30.7\left(\mathrm{~s}, \mathrm{CH}_{3}\right), 56.7\left(\mathrm{~s}, \mathrm{C}_{\mathrm{q}}\right)$. Anal. Calcd for $\mathrm{C}_{8} \mathrm{H}_{18} \mathrm{LiN}_{3}: \mathrm{C}, 58.88 ; \mathrm{H}$, 11.12; N, 25.75. Found: C, 58.88; H, 11.14; N, 25.67.

Bis(1,3-di-tert-butyltriazenide)germanium(II) (1). A solution of (1,3-di-tert-butyltriazenide)lithium(I) $(3.83 \mathrm{~g}, 23.5 \mathrm{mmol})$ in THF $(20 \mathrm{~mL})$ at $-35{ }^{\circ} \mathrm{C}$ was added dropwise to a solution of $\mathrm{GeCl}_{2}$. dioxane $(2.73 \mathrm{~g}, 11.7 \mathrm{mmol})$ in THF $(30 \mathrm{~mL})$ at $-35{ }^{\circ} \mathrm{C}$. The reaction mixture was held at $-35{ }^{\circ} \mathrm{C}$ for $10 \mathrm{~min}$ and then stirred at room temperature for $16 \mathrm{~h}$. The reaction mixture was concentrated under reduced pressure, and the resulting residue was suspended in $n$ hexane, filtered through a pad of Celite, and concentrated under reduced pressure to give the crude product. The crude product was purified by recrystallization from $\mathrm{THF} /$ acetonitrile $(\mathrm{MeCN})$ at -35 ${ }^{\circ} \mathrm{C}$ to give $\mathbf{1}$ as a solid ( $\left.3.39 \mathrm{~g}, 75 \%\right)$.

1: Pale-yellow solid, mp: $82-84{ }^{\circ} \mathrm{C}$. Sublimation: $\sim 60{ }^{\circ} \mathrm{C}(0.5$ mbar). ${ }^{1} \mathrm{H}$ NMR $\left(300 \mathrm{MHz}, \mathrm{C}_{6} \mathrm{D}_{6}\right): \delta 1.40\left(\mathrm{~s}, 36 \mathrm{H}, \mathrm{CH}_{3}\right) .{ }^{13} \mathrm{C}\left\{{ }^{1} \mathrm{H}\right\}$ NMR $\left(125 \mathrm{MHz}, \mathrm{C}_{6} \mathrm{D}_{6}\right): \delta 30.6\left(\mathrm{~s}, \mathrm{CH}_{3}\right), 59.1\left(\mathrm{~s}, \mathrm{C}_{\mathrm{q}}\right)$. EI-MS (LR): 230.1 (100\%), $245.1(<5 \%), 287.1(<5 \%), 329.2(25 \%), 386.2(30 \%)$. Anal. Calcd for $\mathrm{C}_{16} \mathrm{H}_{36} \mathrm{GeN}_{6}$ : C, 49.90; H, 9.42; N, 21.82. Found: C, 49.70; H, 9.40; N, 21.78.

Bis(1,3-di-tert-butyltriazenide)tin(II) (2). A solution of (1,3-di-tertbutyltriazenide)lithium(I) $(1.25 \mathrm{~g}, 7.65 \mathrm{mmol})$ in a $1: 4$ mixture of $\mathrm{Et}_{2} \mathrm{O} / n$-hexane $(5 \mathrm{~mL})$ at $-35{ }^{\circ} \mathrm{C}$ was added dropwise to a suspension of $\mathrm{SnCl}_{2}(0.17 \mathrm{~g}, 0.91 \mathrm{mmol})$ in $n$-hexane $(5 \mathrm{~mL})$ at -35 ${ }^{\circ} \mathrm{C}$ and then stirred at room temperature for $16 \mathrm{~h}$. The reaction mixture was filtered through a pad of Celite and concentrated under reduced pressure to give the crude product. The crude product was purified by recrystallization from $\mathrm{THF} / \mathrm{MeCN}$ at $-35^{\circ} \mathrm{C}$ to give 2 as a solid $(0.79 \mathrm{~g}, 88 \%)$.

2: Yellow solid, mp: $58-59{ }^{\circ} \mathrm{C}$. Sublimation: $\sim 65^{\circ} \mathrm{C}(0.5 \mathrm{mbar})$. ${ }^{1} \mathrm{H}$ NMR (500 MHz, $\left.\mathrm{C}_{6} \mathrm{D}_{6}\right): \delta 1.35\left(\mathrm{~s}, 36 \mathrm{H}, \mathrm{CH}_{3}\right) \cdot{ }^{13} \mathrm{C}\left\{{ }^{1} \mathrm{H}\right\}$ NMR $\left(125 \mathrm{MHz}, \mathrm{C}_{6} \mathrm{D}_{6}\right): \delta 30.6\left(\mathrm{~s}, \mathrm{CH}_{3}\right), 58.9\left(\mathrm{~s}, \mathrm{C}_{\mathrm{q}}\right)$. EI-MS (LR): 134.9 (8\%), 274.1 (8\%), 373.1 (<5\%), 432.2 (25\%). Anal. Calcd for $\mathrm{C}_{16} \mathrm{H}_{36} \mathrm{~N}_{6} \mathrm{Sn}: \mathrm{C}, 44.57 ; \mathrm{H}, 8.41 ; \mathrm{N}, 19.49$. Found: C, 44.04; H, 8.31; $\mathrm{N}, 19.23$.

Bis(1,3-di-tert-butyltriazenide)lead(II) (3). Compound 3 was synthesized in the same manner as 2 using a solution of (1,3-ditert-butyltriazenide)lithium(I) $(1.43 \mathrm{~g}, 8.76 \mathrm{mmol})$ in a $1: 4$ mixture of $\mathrm{Et}_{2} \mathrm{O} / n$-hexane $(20 \mathrm{~mL})$ and a suspension of $\mathrm{PbCl}_{2}(1.22 \mathrm{~g}, 4.39$ $\mathrm{mmol})$ in $n$-hexane $(20 \mathrm{~mL})$. The crude product was purified by recrystallization from $\mathrm{THF} / \mathrm{MeCN}$ at $-35^{\circ} \mathrm{C}$ to give 3 as a solid (1.58 g, 69\%).

3: Yellow solid, mp: $83-84{ }^{\circ} \mathrm{C}$. Sublimation: $\sim 75{ }^{\circ} \mathrm{C}(0.5 \mathrm{mbar})$. ${ }^{1} \mathrm{H}$ NMR (500 MHz, $\left.\mathrm{C}_{6} \mathrm{D}_{6}\right): \delta 1.30\left(\mathrm{~s}, 36 \mathrm{H}, \mathrm{CH}_{3}\right) .{ }^{13} \mathrm{C}\left\{{ }^{1} \mathrm{H}\right\} \mathrm{NMR}$ $\left(125 \mathrm{MHz}, \mathrm{C}_{6} \mathrm{D}_{6}\right): \delta 30.5\left(\mathrm{~s}, \mathrm{CH}_{3}\right), 61.1$ (s, C). Anal. Calcd for $\mathrm{C}_{16} \mathrm{H}_{36} \mathrm{~N}_{6} \mathrm{~Pb}$ : C, 36.98; H, 6.98; N, 16.17. Found: C, 36.56; H, 6.97; $\mathrm{N}, 16.03$.

X-ray Crystallographic Analysis. Single crystals of 1-3 were obtained by recrystallization from $\mathrm{THF} / \mathrm{MeCN}$ at $-35^{\circ} \mathrm{C}$. The single crystals were used for X-ray diffraction data collection on a Bruker D8 SMART Apex-II diffractometer, using graphite-monochromated Mo $\mathrm{K} \alpha$ radiation $(\lambda=0.71073 \AA)$ at $153 \mathrm{~K}$. All data were collected in a hemisphere with over $95 \%$ completeness to $2 \theta<50.05^{\circ}$. The structures were solved by direct methods. The coordinates of the metal atoms were determined from the initial solutions and the $\mathrm{N}$ and $\mathrm{C}$ atoms by subsequent differential Fourier syntheses. The solution did not contain much residual electron density, but it remained for a multitude of additional possible positions of light atoms. All non- $\mathrm{H}$ atoms were refined, first by isotropic and then by anisotropic approximation using Bruker SHELXTL software. The $\mathrm{H}$ atoms were added in a riding approximation and refined isotropically. The solutions of compounds 1 and 2 gave one B-level alert each, which was caused by one atom in each structure failing the Hirshfeld test. These two atoms had significantly bent thermal ellipsoids, potentially caused by more than one preferred orientation for these atoms. These ellipsoids showed no preferred orientation upon manual inspection. Selected crystal data are summarized below.

1: $\mathrm{C}_{16} \mathrm{H}_{36} \mathrm{GeN}_{6}, M=385.12$, monoclinic, space group $P 2 / c, a=$ 9.702(7) $\AA, b=6.055(5) \AA, c=18.549(14) \AA, \alpha=90^{\circ}, \beta=$ $100.971(9)^{\circ}, \gamma=90^{\circ}, V=1069.6(14) \AA^{3}, Z=2, D_{\mathrm{c}}=1.196 \mathrm{~g} \mathrm{~cm}^{-3}, \mu$ $=1.440 \mathrm{~mm}^{-1}, T=153 \mathrm{~K}, 6500$ reflections measured, 1877 unique, final R1 $[I>2 \sigma(I)]=0.0254$, wR2 (all data) $=0.0672$, GOF $=1.040$.

2: $\mathrm{C}_{16} \mathrm{H}_{36} \mathrm{~N}_{6} \mathrm{Sn}, M=431.20$, orthorhombic, space group $P b c n, a=$ 12.732(5) $\AA$, $b=13.049(5) \AA, c=13.693(6) \AA, V=2274.9(16) \AA^{3}, Z$ $=4, D_{\mathrm{c}}=1.259 \mathrm{~g} \mathrm{~cm}^{-3}, \mu=1.131 \mathrm{~mm}^{-1}, T=153 \mathrm{~K}, 16479$ reflections measured, 2051 unique, final $\mathrm{R} 1[I>2 \sigma(I)]=0.0256$, wR2 (all data) $=0.0696, \mathrm{GOF}=0.934$. 
3: $\mathrm{C}_{16} \mathrm{H}_{36} \mathrm{~N}_{6} \mathrm{~Pb}, M=519.70$, orthorhombic, space group Pbcn, $a=$ 12.786(4) $\AA, b=12.794(4) \AA, c=13.734(4) \AA, V=2246.7(12) \AA^{3}, Z$ $=4, D_{\mathrm{c}}=1.536 \mathrm{~g} \mathrm{~cm}^{-3}, \mu=7.518 \mathrm{~mm}^{-1}, T=153 \mathrm{~K}, 15085$ reflections measured, 1982 unique, final R1 $[I>2 \sigma(I)]=0.0236$, wR2 (all data) $=0.0795$, GOF $=0.936$.

TGA. TGA was performed on Pt pans with a TA Instruments Q50 analyzer housed in an MBraun Labmaster 130 dry box filled with $\mathrm{N}_{2}$ (99.998 \% purity). Pt pans were cleaned by ultrasonication, first in dilute nitric acid $(\sim 3 \mathrm{M})$, then water, and last 2-propanol. The pans were heated in air by a propane torch until red hot to remove any remaining impurities. During the TGA experiments of 3 , if the compound decomposes, then $\mathrm{Pb}(0)$ might form and, consequently, alloy with the Pt pans. To avoid potential alloying, pans used for TGA of 3 were coated with a $55 \mathrm{~nm} \mathrm{Al}_{2} \mathrm{O}_{3}$ layer as a precaution. The coating was grown at $200{ }^{\circ} \mathrm{C}$, using trimethylaluminum and water $\left(0.1 \mathrm{~s}\right.$ pulses and $8 \mathrm{~s}$ purges each) for 500 cycles. $^{38}$ All TGA experiments were performed under a flow of ultrapure $\mathrm{N}_{2}$ (99.999\%, $60 \mathrm{sccm}$ ). For ramp experiments, samples were heated to $500{ }^{\circ} \mathrm{C}$ at a rate of $10{ }^{\circ} \mathrm{C} \mathrm{min}^{-1}$. The Langmuir vapor pressure equations for compounds 1-3 were derived from the TGA data with $10 \mathrm{mg}$ of mass loading using a previously reported method ${ }^{39}$ and employing bis(2,2,6,6-tetramethyl-3,5-heptanedionato)copper(II) as the calibrant. ${ }^{40}$ Isothermal TGA were carried out at 90 and $110{ }^{\circ} \mathrm{C}$. A heating rate of $40{ }^{\circ} \mathrm{C} \mathrm{min}{ }^{-1}$ was used to rapidly reach the desired temperature. The experiments were carried out with the same mass loadings as the ramp experiments. The onset of volatilization was defined as the intersection between the tangent lines of the plateau and slope.

DSC Analysis. DSC experiments were performed using a TA Instruments Q10 instrument. Inside a glovebox, samples of $0.30 \pm$ $0.03 \mathrm{mg}$ of 1-3 were sealed in $\mathrm{Al}$ pans. Unless otherwise stated, all samples were heated to $400{ }^{\circ} \mathrm{C}$ at a rate of $10{ }^{\circ} \mathrm{C} \mathrm{min}-1 . \mathrm{N}_{2}$ (99.998\%) was used as the purge gas. Experiments were performed in triplicate with similar mass loadings to ensure validity of the recorded data.

Quantum-Chemical Computations. All quantum-chemical DFT computations were performed using Gaussian 16 software. $^{41}$ Structural optimization and harmonic normal-mode vibrational calculations were done using the B3LYP method ${ }^{42,43}$ together with Grimme's version 3 dispersion correction ${ }^{44}$ and the def2TZVP ${ }^{45,46}$ basis set. Minimized structures were confirmed to have no imaginary frequencies.

\section{ASSOCIATED CONTENT}

\section{(s) Supporting Information}

The Supporting Information is available free of charge at https://pubs.acs.org/doi/10.1021/acs.inorgchem.1c00695.

Characterization of the compounds and computational calculation details (PDF)

\section{Accession Codes}

CCDC 2058914-2058916 contain the supplementary crystallographic data for this paper. These data can be obtained free of charge via www.ccdc.cam.ac.uk/data_request/cif, or by emailingdata_request@ccdc.cam.ac.uk, or by contacting The Cambridge Crystallographic Data Centre, 12 Union Road, Cambridge CB2 1EZ, UK; fax: +44 1223336033.

\section{AUTHOR INFORMATION}

\section{Corresponding Author}

Nathan J. O'Brien - Department of Physics, Chemistry and Biology, Linköping University, Linköping SE-581 83,

Sweden; 이이이.org/0000-0003-3633-9674;

Email: nathan.o.brien@liu.se

\section{Authors}

Rouzbeh Samii - Department of Physics, Chemistry and Biology, Linköping University, Linköping SE-581 83, Sweden; (1) orcid.org/0000-0001-9380-4072

David Zanders - Department of Chemistry, Carleton University, Ottawa, Ontario K1S5B6, Canada; Faculty of Chemistry and Biochemistry, Ruhr University Bochum, Bochum 44801, Germany

Anton Fransson - Department of Physics, Chemistry and Biology, Linköping University, Linköping SE-581 83, Sweden

Goran Bačic - Department of Chemistry, Carleton University, Ottawa, Ontario K1S5B6, Canada

Sean T. Barry - Department of Chemistry, Carleton University, Ottawa, Ontario K1S5B6, Canada; (1) orcid.org/ 0000-0001-5515-4734

Lars Ojamäe - Department of Physics, Chemistry and Biology, Linköping University, Linköping SE-581 83, Sweden; ○ orcid.org/0000-0002-5341-2637

Vadim Kessler - Department of Molecular Sciences, Swedish University of Agricultural Sciences, Uppsala 75007, Sweden

Henrik Pedersen - Department of Physics, Chemistry and Biology, Linköping University, Linköping SE-581 83,

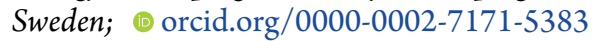

Complete contact information is available at: https://pubs.acs.org/10.1021/acs.inorgchem.1c00695

\section{Notes}

The authors declare no competing financial interest.

\section{ACKNOWLEDGMENTS}

This project was funded by the Swedish Foundation for Strategic Research through the project "Time-resolved low temperature CVD for III-nitrides" (Grant SSF-RMA 15-0018) and by the Knut and Alice Wallenberg Foundation through the project "Bridging the THz gap" (Grant KAW 2013.0049). L.O. acknowledges financial support from the Swedish Government Strategic Research Area in Materials Science on Functional Materials at Linköping University (Faculty Grant SFO Mat LiU no. 2009 00971).

\section{REFERENCES}

(1) Anne, M.-L.; Keirsse, J.; Nazabal, V.; Hyodo, K.; Inoue, S.; Boussard-Pledel, C.; Lhermite, H.; Charrier, J.; Yanakata, K.; Loreal, O.; Le Person, J.; Colas, F.; Compère, C.; Bureau, B. Chalcogenide Glass Optical Waveguides for Infrared Biosensing. Sensors 2009, 9, $7398-7411$

(2) Antunez, P. D.; Buckley, J. J.; Brutchey, R. L. Tin and Germanium Monochalcogenide IV-VI Semiconductor Nanocrystals for Use in Solar Cells. Nanoscale 2011, 3, 2399-2411.

(3) Sinsermsuksakul, P.; Hartman, K.; Bok Kim, S. B.; Heo, J.; Sun, L.; Hejin Park, H.; Chakraborty, R.; Buonassisi, T.; Gordon, R. G. Enhancing the Efficiency of SnS Solar Cells via Band-Offset Engineering with a Zinc Oxysulfide Buffer Layer. Appl. Phys. Lett. 2013, 102, 053901.

(4) Sun, L.; Haight, R.; Sinsermsuksakul, P.; Bok Kim, S. B.; Park, H. H.; Gordon, R. G. Band Alignment of $\operatorname{SnS} / \mathrm{Zn}(\mathrm{O}, \mathrm{S})$ Heterojunctions in SnS Thin Film Solar Cells. Appl. Phys. Lett. 2013, 103, 181904.

(5) Greyson, E. C.; Barton, J. E.; Odom, T. W. Tetrahedral Zinc Blende Tin Sulfide Nano- and Microcrystals. Small 2006, 2, 368-371.

(6) Jiang, T.; Ozin, G. A. New Directions in Tin Sulfide Materials Chemistry. J. Mater. Chem. 1998, 8, 1099-1108.

(7) Stavrinadis, A.; Smith, J. M; Cattley, C. A; Cook, A. G; Grant, P. $S$; Watt, A. A R SnS/PbS Nanocrystal Heterojunction Photovoltaics. Nanotechnology 2010, 21, 185202. 
(8) Sinsermsuksakul, P.; Chakraborty, R.; Kim, S. B.; Heald, S. M.; Buonassisi, T.; Gordon, R. G. Antimony-Doped Tin(II) Sulfide Thin Films. Chem. Mater. 2012, 24, 4556-4562.

(9) Kim, J. Y.; George, S. M. Tin Monosulfide Thin Films Grown by Atomic Layer Deposition Using Tin 2,4-Pentanedionate and Hydrogen Sulfide. J. Phys. Chem. C 2010, 114, 17597-17603.

(10) Bernardes-Silva, A. C.; Mesquita, A. F.; de Moura Neto, E.; Porto, A. O.; de Lima, G. M.; Ardisson, J. D.; Lameiras, F. S. Tin Selenide Synthesized by a Chemical Route: The Effect of Theannealing Conditions in the Obtained Phase. Solid State Commun. 2005, 135, 677-682.

(11) Liu, S.; Guo, X.; Li, M.; Zhang, W.-H.; Liu, X.; Li, C. SolutionPhase Synthesis and Characterization of Single-Crystalline SnSe Nanowires. Angew. Chem., Int. Ed. 2011, 50, 12050-12053.

(12) Mathews, N. R. Electrodeposited Tin Selenide Thin Films for Photovoltaic Applications. Sol. Energy 2012, 86, 1010-1016.

(13) Moon, D. G.; Rehan, S.; Yeon, D. H.; Lee, S. M.; Park, S. J.; Ahn, S. J.; Cho, Y. S. A Review on Binary Metal Sulfide Heterojunction Solar Cells. Sol. Energy Mater. Sol. Cells 2019, 200, 109963.

(14) Yeon, D. H.; Mohanty, B. C.; Lee, C. Y.; Lee, S. M.; Cho, Y. S. High-Efficiency Double Absorber PbS/CdS Heterojunction Solar Cells by Enhanced Charge Collection Using a $\mathrm{ZnO}$ Nanorod Array. ACS Omega 2017, 2, 4894-4899.

(15) Safrani, T.; Kumar, T. A.; Klebanov, M.; Arad-Vosk, N.; Beach, R.; Sa'ar, A.; Abdulhalim, L.; Sarusi, G.; Golan, Y. Chemically Deposited $\mathrm{PbS}$ Thin Film Photo-Conducting Layers for Optically Addressed Spatial Light Modulators. J. Mater. Chem. C 2014, 2, 9132-9140.

(16) Lee, S. M.; Jang, W.; Mohanty, B. C.; Yoo, J.; Jang, J. W.; Kim, D. B.; Yi, Y.; Soon, A.; Cho, Y. S. Experimental Demonstration of In Situ Stress-Driven Optical Modulations in Flexible Semiconducting Thin Films with Enhanced Photodetecting Capability. Chem. Mater. 2018, 30, 7776-7781.

(17) Carrillo-Castillo, A.; Salas-Villasenor, A.; Mejia, I.; AguirreTostado, S.; Gnade, B. E.; Quevedo-López, M. A. P-Type Thin Films Transistors with Solution-Deposited Lead Sulfide Films as Semiconductor. Thin Solid Films 2012, 520, 3107-3110.

(18) Navale, S. T.; Bandgar, D. K.; Chougule, M. A.; Patil, V. B. Facile Method of Preparation of PbS Films for $\mathrm{NO}_{2}$ Detection. RSC Adv. 2015, 5, 6518-6527.

(19) Beatriceveena, T. V.; Prabhu, E.; Sree Rama Murthy, A.; Jayaraman, V.; Gnanasekar, K. I. Highly Selective PbS Thin Film Based Ammonia Sensor for Inert Ambient: In-Situ Hall and Photoelectron Studies. Appl. Surf. Sci. 2018, 456, 430-436.

(20) George, S. M. Atomic Layer Deposition: An Overview. Chem. Rev. 2010, 110, 111-131.

(21) Hatanpää, T.; Ritala, M.; Leskelä, M. Precursors as Enablers of ALD Technology: Contributions from University of Helsinki. Coord. Chem. Rev. 2013, 257, 3297-3322.

(22) Koponen, S. E.; Gordon, P. G.; Barry, S. T. Principles of Precursor Design for Vapour Deposition Methods. Polyhedron 2016, $108,59-66$.

(23) Gordon, R. G. Atomic Layer Deposition for Semiconductors. In Atomic Layer Deposition for Semiconductors; Hwang, C. S., Yoo, C. Y., Eds.; Springer: New York, 2014; pp 15-46.

(24) Puurunen, R. Surface Chemistry of Atomic Layer Deposition: A Case Study for the Trimethylaluminum/Water Process. J. Appl. Phys. 2005, 97, 121301.

(25) Kim, S. B.; Sinsermsuksakul, P.; Hock, A. S.; Pike, R. D.; Gordon, R. G. Synthesis of N-Heterocyclic Stannylene (Sn(II)) and Germylene (Ge(II)) and a Sn(II) Amidinate and Their Application as Precursors for Atomic Layer Deposition. Chem. Mater. 2014, 26, 3065-3073.

(26) Yoo, C.; Kim, W.; Jeon, J. W.; Park, E. S.; Ha, M.; Lee, Y. K.; Hwang, C. S. Atomic Layer Deposition of $\mathrm{Ge}_{\mathrm{x}} \mathrm{Se}_{1-\mathrm{x}}$ Thin Films for Endurable Ovonic Threshold Selectors with a Low Threshold Voltage. ACS Appl. Mater. Interfaces 2020, 12, 23110-23118.
(27) Sinsermsuksakul, P.; Heo, J.; Noh, W.; Hock, A. S.; Gordon, R. G. Atomic Layer Deposition of Tin Monosulfide Thin Films. Adv. Energy Mater. 2011, 1, 1116-1125.

(28) Kim, S. B.; Zhao, X.; Davis, L. M.; Jayaraman, A.; Yang, C.; Gordon, R. G. Atomic Layer Deposition of Tin Monosulfide Using Vapor from Liquid $\operatorname{Bis}\left(N, N^{\prime}\right.$-diisopropylformamidinato)tin(II) and $\mathrm{H}_{2}$ S. ACS Appl. Mater. Interfaces 2019, 11, 45892-45902.

(29) Popov, G.; Bačić, G.; Mattinen, M.; Manner, T.; Lindström, H.; Seppänen, H.; Suihkonen, S.; Vehkamäki, M.; Kemell, M.; Jalkanen, P.; Mizohata, K.; Räisänen, J.; Leskelä, M.; Koivula, H. M.; Barry, S. T.; Ritala, M. Atomic Layer Deposition of PbS Thin Films at Low Temperatures. Chem. Mater. 2020, 32, 8216-8228.

(30) Karsch, H. H.; Schlüter, P. A.; Reisky, M. Bis(amidinate) Complexes of Silicon and Germanium. Eur. J. Inorg. Chem. 1998, 1998, 433-436.

(31) Chlupatý, T.; Padělková, Z.; Lyčka, A.; Brus, J.; Rưžička, A. Reactivity of Lithium n-Butyl Amidinates towards Group 14 Metal(II) Chlorides Providing Series of Hetero- and Homoleptic Tetrylenes. Dalton Trans. 2012, 41, 5010-5019.

(32) Flanagan, K. R.; Parish, J. D.; Fox, M. A.; Johnson, A. L. Synthetic, Structural, and Computational Studies on Heavier Tetragen and Chalcogen Triazenide Complexes. Inorg. Chem. 2019, $58,16660-16666$.

(33) Samii, R.; Zanders, D.; Buttera, S. C.; Kessler, V.; Ojamäe, L.; Pedersen, H.; O'Brien, N. J. Synthesis and Thermal Study of Hexacoordinated Aluminum(III) Triazenides for Use in Atomic Layer Deposition. Inorg. Chem. 2021, 60, 4578-4587.

(34) Rouf, P.; Samii, R.; Rönnby, K.; Bakhit, B.; Buttera, S. C.; Martinovic, I.; Ojamäe, L.; Hsu, C.-W.; Palisaitis, J.; Kessler, V.; Pedersen, H.; O’Brien, N. J. Hexacoordinated Gallium(III) Triazenide Precursor for Epitaxial Gallium Nitride by Atomic Layer Deposition. Chem. Mater. 2021, 33, 3266-3275.

(35) O’Brien, N. J.; Rouf, P.; Samii, R.; Rönnby, K.; Buttera, S. C.; Hsu, C.-W.; Ivanov, I. G.; Kessler, V.; Ojamäe, L.; Pedersen, H. In Situ Activation of an Indium(III) Triazenide Precursor for Epitaxial Indium Nitride by Atomic Layer Deposition. Chem. Mater. 2020, 32, 4481-4489.

(36) Rosiak, D.; Okuniewski, A.; Chojnacki, J. Novel Complexes Possessing $\mathrm{Hg}-(\mathrm{Cl}, \mathrm{Br}, \mathrm{I}) \cdots \mathrm{O}=\mathrm{C}$ Halogen Bonding and Unusual $\mathrm{Hg}_{2} \mathrm{~S}_{2}(\mathrm{Br} / \mathrm{I})_{4}$ Kernel. The Usefulness of $\mathrm{T}_{4}{ }^{\prime}$ Structural Parameter. Polyhedron 2018, 146, 35-41.

(37) Bottaro, J. C.; Penwell, P. E.; Schmitt, R. J. Expedient Synthesis of t-Butyl Azide. Synth. Commun. 1997, 27, 1465-1467.

(38) Bačić, G.; Zanders, D.; Mallick, B.; Devi, A.; Barry, S. T. Designing Stability into Thermally Reactive Plumbylenes. Inorg. Chem. 2018, 57, 8218-8226.

(39) Kunte, G. V.; Shivashankar, S. A.; Umarji, A. M. Thermogravimetric Evaluation of the Suitability of Precursors for MOCVD. Meas. Sci. Technol. 2008, 19, 025704.

(40) Colominas, C.; Lau, K. H.; Hildenbrand, D. L.; Crouch-Baker, S.; Sanjurjo, A. Vapor Pressures of the Copper and Yttrium $\beta$ Diketonate MOCVD Precursors. J. Chem. Eng. Data 2001, 46, 446450.

(41) Frisch, M. J.; Trucks, G. W.; Schlegel, H. B.; Scuseris, G. E.; Robb, M. A.; Cheeseman, J. R.; Scalmani, G.; Barone, V.; Petersson, G. A.; Nakatsuji, H.; Li, X.; Caricato, M.; Marenich, A. V.; Bloino, J.; Janesko, B. G.; Gomperts, R.; Mennucci, B.; Hratchian, H. P.; Ortiz, J. V.; Izmaylov, A. F.; Sonnenberg, J. L.; Williams-Young, D.; Ding, F.; Lipparini, F.; Egidi, F.; Goings, J.; Peng, B.; Petrone, A.; Henderson, T.; Ranasinghe, D.; Zakrzewski, V. G.; Gao, J.; Rega, N.; Zheng, G.; Liang, W.; Hada, M.; Ehara, M.; Toyota, K.; Fukuda, R.; Hasegawa, J.; Ishida, M.; Nakajima, T.; Honda, Y.; Kitao, O.; Nakai, H.; Vreven, T.; Throssell, K.; Montgomery, J. A., Jr.; Peralta, J. E.; Ogliaro, F.; Bearpark, M. J.; Heyd, J. J.; Brothers, E. N.; Kudin, K. N.; Staroverov, V. N.; Keith, T. A.; Kobayashi, R.; Normand, J.; Raghavachari, K.; Rendell, A. P.; Burant, J. C.; Iyengar, S. S.; Tomasi, J.; Cossi, M.; Millam, J. M.; Klene, M.; Adamo, C.; Cammi, R.; Ochterski, J. W.; Martin, R. L.; Morokuma, K.; Farkas, O.; Foresman, J. B.; Fox, D. J. Gaussian 16, revision B.01; Gaussian Inc.: Wallingford, CT, 2016, 
(42) Hanson-Heine, M. W. D.; George, M. W.; Besley, N. A. Calculating Excited State Properties Using Kohn-Sham Density Functional Theory. J. Chem. Phys. 2013, 138, 064101.

(43) Lee, C.; Yang, W.; Parr, R. G. Development of the Colle-Salvetti Correlation-Energy Formula into a Functional of the Electron Density. Phys. Rev. B: Condens. Matter Mater. Phys. 1988, 37, 785-789.

(44) Grimme, S.; Antony, J.; Ehrlich, S.; Krieg, H. A Consistent and Accurate $\mathrm{Ab}$ Initio Parametrization of Density Functional Dispersion Correction (DFT-D) for the 94 Elements H-Pu. J. Chem. Phys. 2010, 132, 154104.

(45) Weigend, F.; Ahlrichs, R. Balanced Basis Sets of Split Valence, Triple Zeta Valence and Quadruple Zeta Valence Quality for $\mathrm{H}$ to Rn: Design and Assessment of Accuracy. Phys. Chem. Chem. Phys. 2005, 7, 3297-3305.

(46) Metz, B.; Stoll, H.; Dolg, M. Small-Core MulticonfigurationDirac-Hartee-Fock-Adjusted Pseudopotentials for Post-d Main Group Elements: Application to $\mathrm{PbH}$ and PbO. J. Chem. Phys. 2000, 113, $2563-2569$.

\section{NOTE ADDED AFTER ASAP PUBLICATION}

This article was published ASAP on August 6, 2021. The Experimental Section has been added and the Supporting Information file was updated. The corrected version reposted on August 12, 2021. 